\title{
Correction to: The influence of renewable energy use, human capital, and trade on environmental quality in South Africa: multiple structural breaks cointegration approach
}

\author{
Paul Terhemba Iorember ${ }^{1} \cdot$ Gylych Jelilov ${ }^{2} \cdot$ Ojonugwa Usman $^{3}$ (I) $\cdot$ Abdurrahman Işık $^{2} \cdot$ Bilal Celik $^{2}$ \\ Published online: 3 December 2020 \\ (C) Springer-Verlag GmbH Germany, part of Springer Nature 2020
}

\section{Correction to: Environmental Science and Pollution Research} https://doi.org/10.1007/s11356-020-11370-2

The correct 1st sentence of the Abstract is "Recent economic and environmental literature suggests that the current state of energy use in South Africa amidst rapid growing population is unsustainable."

The original article was corrected.

Publisher's note Springer Nature remains neutral with regard to jurisdictional claims in published maps and institutional affiliations.

The online version of the original article can be found at https://oi.org/ $10.1007 / \mathrm{s} 11356-020-11370-2$

Ojonugwa Usman

usmanojonugwa@gmail.com

1 Faculty of Social Sciences, Nile University of Nigeria,

Abuja, Nigeria

2 Department of Economics, Nile University of Nigeria, Abuja, Nigeria

3 School of Business Education Federal College of Education (Technical), Potiskum, Yobe State, Nigeria 